spola/roda u obavljanju upravljačkih poslova osobito u kontekstu osjećaja neravnopravnosti koja nije samo uzrokovana funkcioniranjem patrijarhalnih struktura nego, prema njihovu mišljenju, i oklijevanjem i nesigurnošću žena da preuzmu odgovornije poslove. Pritom se brojnost žena na upravljačkim položajima u kulturnom sektoru tumači u kontekstu njegova određenja kao društvenog života »izvan stvarne moći«. Žene na upravljačkim položajima u kulturi ostvaruju netipične karijere ispunjene mnoštvom prepreka, svoj posao rijetko kada izjednačuju s karijerom, određuju ga izrazito nesigurnim te s velikom dozom opreza barataju pojmom »ambicioznost« - srameći ga se, ne vezujući ga samo uz poslovni nego i uz obiteljski život. Njihova upravljačka moć nailazi na različita sektorska unutarnjeorganizacijska i vanjska ograničenja pri čemu spolno/rodni faktor nije jedno od njih. Menadžerice u načelu nemaju problem s »ljepljivim podovima« ili »staklenim stropovima«. $\mathrm{Na}$ to se nastavlja cijeli niz stavova vezanih uz procjenu osobina feminističkih inicijativa - od eklatantno antifeminističkih stavova, do onih s »figom u džepu« koje autorica opisuje kao »nisam feministica, ali...« pa sve do afirmativnih stavova. Paradoksalno, neke su ispitanice pokazale svojevrsnu skepsu prema ženskim postignućima u profesiji, temeljeći svoje stavove na uvjerenju o ženskoj iskonskoj kvarnosti te na kritici ženske nesolidarnosti.

$\mathrm{Na}$ kraju autorica iznosi niz prijedloga i sugestija vezanih uz kulturne i rodne politike koje podrazumijevaju okretanje prema privatnom i civilnom sektoru, cjelovite institucionalne promjene, sustavnu rodnu strategiju u različitim društvenim područjima kao i promišljen državni feminizam koji bira nove smjerove osim onih okrenutih prema pravima majki i obitelji. Njezina je pozicija, od koje ne odustaje ni $\mathrm{u}$ jednom dijelu svoje knjige, pritom uvijek duboko kritična, nikada jednostrana ili isključiva i nikada svodiva na jednostavna rješenja. Zaključno možemo ustvrditi, pozivajući se na sukus stavova recenzenata, da knjiga Žene $i$ društvena moć, osim velike autorske kompetentnosti u obavljanju zahtjevnog i kompleksnog znanstvenog zadatka, predstavlja i nezaobilazni standard u europskoj akademskoj literaturi koja promišlja pojmove roda, moći i kulture.

Ana Maskalan

Institut za društvena istraživanja u Zagrebu

DOI: $10.5613 /$ rzs.42.3.5

Manuel Castells

\section{Networks of Outrage and Hope: Social Movements in the Internet Age}

Cambridge: Polity Press, 2012, 300 str.

Za razliku od onih koji su im prethodili, suvremeni društveni pokreti poka- 
zuju nekoliko specifičnih karakteristika koje zahtijevaju detaljnu analizu želi li se vidjeti posljedice njihova djelovanja i budućnost promjena na kojima inzistiraju. Zbog tih razloga knjiga Networks of Outrage and Hope: Social Movements in the Internet Age (Mreže bijesa $i$ nade: društveni pokreti $u$ doba interneta) Manuela Castellsa predstavlja važan pothvat u nastojanju da se obuhvate različite predispozicije nastajanja i djelovanja tih društvenih pokreta, posebice u kontekstu digitalno-interaktivnog medijskog sustava.

Castells u knjizi nastoji pružiti dovoljno opisnoga, konceptualnog i teorijskog materijala koji bi otvorio put razumijevanju nastajanja društvenih pokreta u 21. stoljeću, počevši s analizom globalnoga političkog, ekonomskog i kulturnog stanja za koje smatra da su bili važni okidači različitih ustanaka i revolucija. Konceptualni okvir prema kojem je autor gradio knjigu jest svojevrsna »utemeljena teorija $u$ nastajanju«, a koja bi trebala proizvesti radne hipoteze kao doprinos sistematiziranijem znanstvenom odnosu prema novim društvenim pokretima. Castells oprezno izbjegava determinističke elemente odnosa medijske tehnologije i društva, upozoravajući pritom da internet nije uzrok spomenutim društvenim promjenama, kako onima u arapskim zemljama, tako i onima u zapadnim društvima na čijim primjerima gradi svoju analizu. No, ignoriranje komunikacijskih specifičnosti digitalno-interaktivnih medijskih sustava u povezivanju različitih aktera i različitih mreža, a u svrhu šire- nja organiziranih akcija, ideja i ciljeva društvenih pokreta, također predstavlja svojevrsni metodološki redukcionizam. Važni koncepti preko kojih treba graditi razumijevanje položaja i uloge novih društvenih pokreta još uvijek se kreću oko institucije države i njezina monopola primjene sile, legitimnosti društvenog poretka te mogućnosti umreživanja prosvjednika. Riječ je o odnosima čija se interakcija simultano odvija u offline i online prostoru. Castells također spominje i važnost emocionalnih stanja kao važnih okidača širega društvenog nezadovoljstva izraženog kroz različite oblike ustanaka i revolucionarnih prevrata, izdvajajući pritom bijes kao glavni katalizator predbuntovnog stanja i nadu bez koje se bijes lišen konkretne društvene akcije pretvara samo u rezigniranost i apatiju (str. 13).

Osim emocionalnog stanja i još uvijek važne uloge države, Castells smatra da su modeli mrežnog organiziranja, odnosno multimodalne mreže (multimodal networks), važni zbog svoje komunikacijske moći, naročito u smislu kreiranja autonomnog prostora komunikacije u digitalnim prostorima tokova (space of flows) kao važnoga predakcijskog elementa zabilježenog u svim analiziranim pokretima u knjizi.

Bijes je akumuliran zatečenim stanjem u specifičnom društvu (ekonomska i politička disfunkcionalnost), a upravo su multimodalni modeli komunikacije važni za njegovu daljnju diseminaciju i akumulaciju na široj društvenoj razini. Međutim, ako izostanu elementi zauzimanja javnih prostora kao prostora slo- 
bodnih zajednica, onda pokret gubi na važnoj simboličkoj dimenziji svog djelovanja, a gubi se i kontekst u kojem se prevladava strah kao važna emocionalna prepreka širenju pokreta. U trenutku zauzimanja javnih urbanih površina, društveni pokreti postaju hibridi offline i online komunikacijskih prostora, djelujući istodobno $\mathrm{u}$ fizičkom prostoru $\mathrm{i} \mathrm{u}$ prostoru tokova.

Taj konceptualni i teorijski okvir Castells primjenjuje kroz šest glavnih poglavlja svoje knjige na različite društvene kontekste diljem svijeta, kao i na različite primjere umreženih društvenih pokreta.

Kroz poglavlje »Prelude to Revolution« (»Preludij za revoluciju«) Castells detaljno opisuje povijesne, ekonomske i političke razloge revolucionarnih prevrata koji pripadaju kolokvijalnom terminu »Arapskog proljeća«, analizirajući istodobno važnost uspjeha koje su postigli pokreti u Tunisu i Islandu jer su ponudili važan element nade za pokrete koji su nastali inspirirani njihovim uspjesima. Svakako važan element koji se provlači kroz sve ostale analizrane pokrete jest visok udio mladih, nezaposlenih i visokobrazovanih prosvjednika, posebice kao onih aktera $\mathrm{u}$ pokretu koji su zaslužni za upravljanje informacijama i njihovu diseminaciju putem digitalno-interaktivnih medijskih sustava. Primjer Islanda, s druge strane, služi kao svojevrsni kontrapunkt tuniškom kontekstu jer je riječ o dijametralno suprotnim političkim i ekonomskim prilikama. Naime, dok je u Tunisu pokret nastao zbog permanen- tnoga policijskog ugnjetavanja i korupcije, na Islandu prosvjedi nastupaju kao odgovor na krizu predstavničke demokracije koja nije pokazala dovoljno snage, političke volje i umješnosti da odgovori na koruptivne postupke financijskog sektora. Kao i u slučaju Tunisa, komunikacija putem digitalno-interaktivnih medijskih platformi pokazala se važnim elementom povezivanja aktera u širu društvenu akciju, tim više jer rasprostranjenost internetske tehnologije na Islandu iznosi visokih 95\% (str. 34). Takozvana »revolucija kuhinjskog posuđa« (kitchenware revolution) krenula je spontanim okupljanjem ispred islandskog parlamenta te je svojim permanentnim angažmanom u digitalnom i fizičkom prostoru dovela do rušenja stranke na vlasti, zamijenivši je na sljedećim, prijevremenim, parlamentarnim izborima lijevo-zelenom koalicijom. Castells zaključuje kako je važnost tih revolucijskih "preludija« u razumijevanju »međuodnosa kulture, institucija i pokreta kao ključnih pitanja za teoriju društvene promjene« (str. 46).

Poglavlje »The Egyptian Revolution« (»Egipatska revolucija«) donosi slične okvire analize gdje se autor ponovno osvrće na strukturu prosvjednika te posebice na ulogu skupina na internetskim društvenim mrežama (poput »Mi smo Khaled Said«, skupine nastale u spomen na aktivista kojeg je policija usmrtila u prosvjedima 2010.), ali i ulogu individualnih mreža, kao i mreža navijača nogometnih klubova (Al-Ahly i Zamalek). Pogled na strukturu prosvjednika pokazuje slične ten- 
dencije kao i kod tuniških i islandskih pokreta, gdje dominiraju mahom mladi u dobi između 20 i 40 godina, posebice u samim počecima organiziranih akcija i djelovanja. Uskoro se počinju pridruživati ostale društvene skupine, zajedno $\mathrm{s}$ različitim religijskim manjinama (kršćanski Kopti). Castells nanovo naglašava podatak o visokoj rasprostranjenosti mobilne tehnologije, odnosno podatak prema kojem je 2010. zabilježeno da $80 \%$ Egipćana posjeduje neki oblik mobilnog telefona. No, jednako tako naglašava važnost klasičnih modela komunikacije, posebice kad je u pitanju dopiranje do siromašnijih slojeva stanovništva u slamovima putem distribucije letaka. Možda najzanimljiviji element za analizu egipatske revolucije dolazi u obliku reakcije na isključivanje interneta od strane režima. Unatoč željenom efektu smanjenja intenziteta prosvjeda, taj je čin uspio napraviti štetu jedino egipatskoj ekonomiji te je nakon samo četiri dana blokade komunikacijski promet ponovno uspostavljen. Castells također misli da su postojale razlike između različitih društvenih slojeva s obzirom na ciljeve prosvjeda. Siromašni su zahtijevali poboljšanje svoga ekonomskog položaja, dok je srednji sloj obrazovanih urbanih mladih prosvjedovao zbog političkog stanja $u$ zemlji. Egipatska revolucija, osim što je nosila značaje hibridnosti djelovanja i komunikacije, specifična je i zbog nastojanja žena da poboljšaju svoj položaj u društvu, a što je redovito rezultiralo brutalnim nasilnim reakcijama prema aktericama s obiju suprotstavljenih stra- na. (I to unatoč činjenici da je možda glavni komunikacijski okidač prosvjeda bio videoblog mlade Egipćanke Asmae Mahfouz.) Uspjeh egipatske revolucije Castells vidi u kombiniranim čimbenicima bijesa i nade (inspiracija uspjehom tuniške revolucije), raskoraku državnog režima s globalnim ekonomskim trendovima (koji su doveli do širenja društvenih razlika i porasta siromaštva) te gubitku legitimnosti političkih elita u egipatskom društvu.

U poglavlju »Dignity, Violence, Geopolitics« (»Dignitet, nasilje, geopolitika «) Castells razmatra perspektive ustanaka u ostalim arapskim zemljama, uz napomenu kako za svaki od tih ustanaka valja uzeti u obzir lokalne političke, kulturne i ekonomske specifičnosti. Posebnim elementom smatra unutarnje i geopolitičke uvjete svake države posebno, a što je onda vezano i za načine na koje je odgovarano na prosvjede, bilo da je riječ primjerice o demokratskim izmjenama ustava ili o nasilnom gušenju prosvjeda. Njegovo je mišljenje kako je širina nasilnih mjera uvjetovana snagom legitimnosti svakoga pojedinog režima u društvu. Također, prema njegovu mišljenju, kontinuirana patpozicija između suprotstavljenih strana ostavlja mogućnost eskalacije sukoba u otvoreni oružani sukob, apostrofirajući pritom Libiju gdje je, zbog specifičnosti konteksta, teško bio ostvariv mirni prevrat ili kompromis kakav je zabilježen u drugim zemljama. Ovakav put, prema Castellsu, otvara opasnost da se društveni pokreti transformiraju u oružane organizirane skupine, a što u ko- 
načnici znači suspenziju demokratskih načela te potencijal da se metodama borbe izjednače s ugnjetavačima protiv kojih su se do maloprije borili. Na kraju, Castells se još jednom vraća ulozi digitalno-interaktivnih medija u generiranju »Arapskog proljeća« koje smatra važnima za različite »organizacijske oblike, kulturne ekspresije i specifične oblike političke autonomije« društvenih pokreta (str. 103) bez kojih bi tijek tih revolucija imao vrlo vjerojatno drukčiji ishod. Drugim riječima, digitalni mediji su imali veliku ulogu utoliko što su pružili nužnu komunikacijsku infrastrukturu prosvjedima.

$\mathrm{U}$ poglavljima »Rhizomatic Revolution« (»Rizomatska revolucija«) i »Occupy Wall Street« (»Zauzmite Wall Street«) Castells preusmjerava fokus $\mathrm{s}$ arapskih zemalja na one zapadnih demokratskih društava, točnije na primjere pokreta i prosvjeda u Španjolskoj i Sjedinjenim Američkim Državama. Izvori bijesa u Španjolskoj su se, kao i kod drugih pokreta, počeli pojavljivati u digitalnim komunikacijskim sferama, no ubrzo je slijedilo i zauzimanje javnih urbanih površina. Castells, s obzirom da je djelomično sudjelovao u španjolskim prosvjedima, nešto više prostora ostavlja njihovoj analizi, opisujući regulacijske i komunikacijske prakse prosvjednika kako unutar samog pokreta tako i prema drugim mrežama i javnosti. Analiza diskursa prosvjednih skupina pokazala je da postoje višestruki ciljevi, ali da je načelno riječ o pokretu bez programa. Osim izostanka jasne programske platforme, španjolski (ali i američki pokret) pokazuje strukutru u kojoj ne postoji rigidna hijerarhija, birokratizacija procesa donošenja odluka niti jasno definirano vodstvo. Također, i jedan i drugi pokret svoje aktivnosti kreiraju prema nenasilnim metodama djelovanja, istodobno razvijajući strategiju otpora prema policijskoj represiji koja je nastupila vrlo brzo nakon zauzimanja urbanih javnih površina. Specifičnost tih pokreta, za razliku od onih u arapskim zemljama i onoga na Islandu, jest neuspjeh u promjeni političko-demokratskog sustava zemlje te u konačnici osipanje aktivnosti na javnim urbanim površinama. Castells pritom postavlja pitanje kakva je sudbina i utjecaj tih pokreta u takvom kontekstu te smatra da su ti pokreti, upravo inzistirajući na aktivnostima koje nisu orijentirane na produktivnost i striktno definirane ciljeve, dugoročno važniji za mijenjanje vrijednosnih dimenzija društava jer ostavljaju permanentni trag u kolektivnoj svijesti društva. Također, nastavljanjem aktivnosti u digitalnom komunikacijskom kontekstu, njihov utjecaj ostaje još uvijek prisutan u svakodnevnom životu ljudi.

Poglavljem »Changing the World in Network Society« (»Mijenjanje svijeta u umreženom društvu«) Castells sumira temeljne elemente analiza i pregleda različitih pokreta. Glavna obilježja svode se na umreženost $u$ višestrukim oblicima: multimodalnost, offline i online mreže unutar pokreta kao i umreženost prema drugim pokretima. Tekuća održivost je moguća jedino permanentnom prisutnošću u online svijetu. Također, riječ je o pokretima koji su is- 
todobno i globalni i lokalni jer potporu kao i potencijalne podružnice imaju izvan svoga, zadanog, društvenog konteksta. Castells umrežene pokrete vidi i kao pokrete koji su visoko samorefleksivni te ciljno orijentirani na mijenjanje društvenih vrijednosti. Budućnost njihovog utjecaja još je daleko od izvjesne, no autor smatra da je nastavkom teorijske i empirijske analize i interpretacije moguće preciznije predvidjeti konačan ishod njihove uloge u umreženom društvu.

Knjiga Networks of Outrage and Hope: Social Movements in the Inter- net Age važna je zbog nastojanja da se sistematizira analitička građa o društvenim pokretima u globalnom digitalnom kontekstu umreženog društva. Iako nije precizna i sistematična poput $\mathrm{Ca}-$ stellsove trilogije o usponu umreženog društva, svejedno pruža koristan materijal s kojim se mogu primjereno obraditi slične pojave i u hrvatskom kontekstu, kao na primjeru društvene uloge i budućnosti pokreta poput Occupy Croatia i Annonymous Croatia.

Krešimir Krolo Odjel za sociologiju, Sveučilište u Zadru 